\title{
Capital Flows and the Swiss Franc
}

Pinar Yeşin

JEL-classification: F21, F31, F32

Keywords: Exchange rate, safe haven currency, gross capital flows, net flows, private flows.

\section{SUMMARY}

The Swiss franc is known to appreciate strongly during financial market turmoil, demonstrating its status as a typical safe haven currency. One possible mechanism behind this appreciation during times of global turmoil is assumed to be higher capital inflows to Switzerland. This paper attempts to find some empirical evidence for this presumption. The analysis reveals that capital flow variables are not necessarily coincident with the movements of the Swiss franc. Interest rate differentials, a traditional determinant of exchange rates, co-move only weakly with Swiss franc movements. However, a robust and stronger link between variables that capture global or regional market uncertainty and movements of the Swiss franc is observed. Specifically, the information channel rather than new cross-border investment is found to be coincident with the Swiss franc. The weak link between capital flows and the exchange rate is confirmed to some extent for some other countries.

a Swiss National Bank, Börsenstrasse 15, P.O. Box, CH-8022 Zürich, Switzerland, pinar. yesin@snb.ch. I thank two anonymous referees, Philippe Bacchetta, Adrian Bruhin, Andreas Fischer, Christian Grisse, Henrike Groeger, Christoph Meyer, seminar participants at the Swiss National Bank, and conference participants at the 2013 Conference of the Swiss Society of Economics and Statistics in Neuchâtel for their helpful comments and discussions. I also thank Elisabeth Beusch and Henrike Groeger, who provided excellent research assistance at different stages of this project. Any remaining errors are my own. The views expressed in this paper are those of the author and do not represent those of the Swiss National Bank. 


\section{Introduction}

Numerous papers have shown that the Swiss franc (CHF) exhibits safe haven characteristics. For example, Ranaldo and Söderlind (2010) find that the $\mathrm{CHF}$ is a safe haven currency because it provides a hedge in normal times and a further return during global turmoil. ${ }^{1}$ Indeed, Figure 1 provides graphical evidence that between January 2000 and July 2015, the CHF tended to appreciate in real trade-weighted terms during periods of increased uncertainty in European financial markets (shaded columns in the figure). In the figure, periods of increased uncertainty in Europe are defined in the spirit of DE BOCK and DE Carvalho Filho (2015). During these periods, the volatility index of EURO STOXX 50 (VSTOXX) exhibited a steep and sudden increase owing to a rise in risk perception in Europe. Figure 1 further indicates the period between September 2011 and January 2015 with two vertical lines during which the Swiss National Bank (SNB) implemented an exchange rate floor of 1 euro $=1.20 \mathrm{CHF}$. At first glance, Figure 1 confirms that the $\mathrm{CHF}$ has strongly appreciated during periods of regional turmoil, especially between 2008 and 2011.

International financial institutions and the financial press usually mention two possible mechanisms through which safe haven currencies appreciate during turmoil in financial markets: first, global unwinding of carry trade positions in lowyielding currencies; second, increased capital flows to safer political and economic environments. Both mechanisms are believed to create an increased demand for safe haven currencies, which results in appreciation pressure. Indeed, the strong appreciation of the CHF during the global financial and European sovereign debt crises was mainly attributed to higher capital inflows to Switzerland according to international financial institutions. For example, the IMF (2012) states that "[s]afe-haven capital inflows from the euro zone turmoil pushed the exchange rate to new heights last summer, just as slower global economic activity was curtailing export growth." Similarly, the OECD (2011) asserts that "[t]he trade-weighted real exchange rate appreciated to record levels as the Swiss franc benefited from capital inflows in the context of turbulence in some euro area debt markets."

1 Additional papers that confirm the safe haven characteristics of the CHF are Hossfeld and MacDonald (2015), Grisse and Nitschka (2015), de Bock and de Carvalho Filho (2015), Habib and Stracca (2012), Habib and Stracca (2013), de Carvalho Filho (2015), HoffMANN and Suter (2010), and KUgler and Weder (2005), among others. 
Figure 1: REER of the Swiss Franc and Heightened Volatility in European Financial Markets

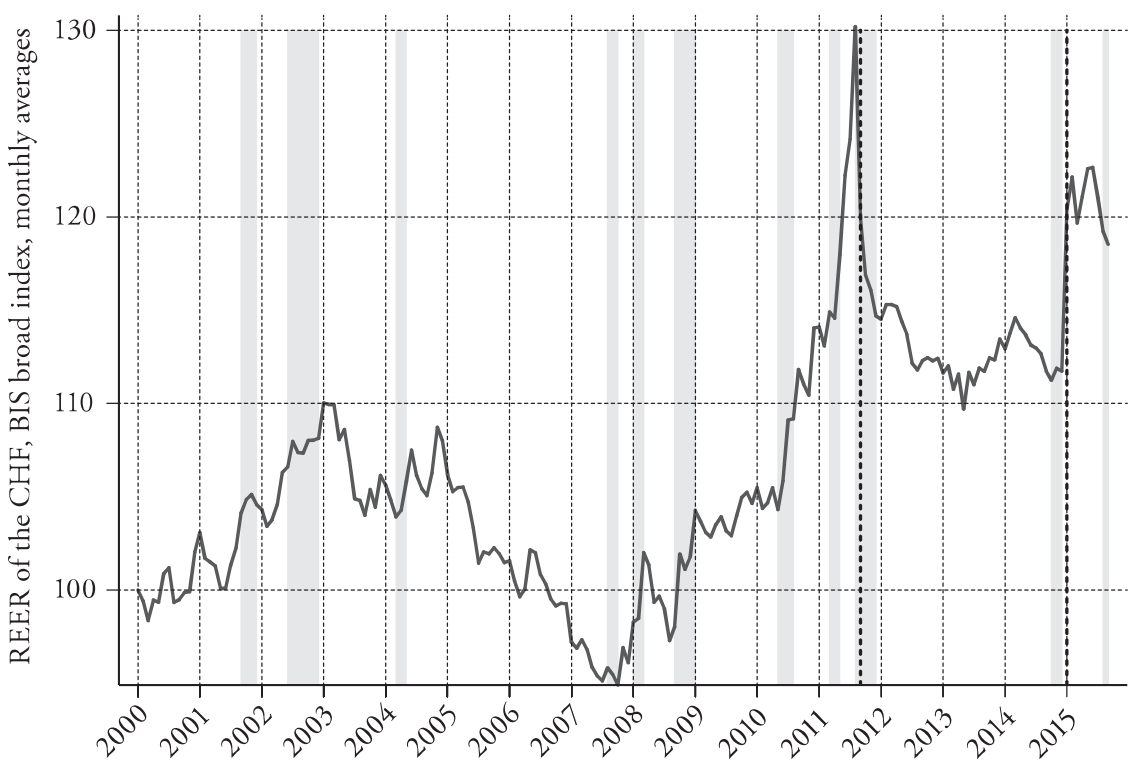

Sources: Bank for International Settlements, Datastream, and author's calculations.

Notes: The figure is inspired by De CARvalho Filho (2015). The real effective exchange rate (REER) of the Swiss franc is based on a broad basket and the CPI. An increase indicates an appreciation of the Swiss franc. Monthly averages are depicted. January $2000=100$. Shaded columns denote periods of heightened volatility in European financial markets (i.e., regional turmoil) based on Europe's perceived volatility index, the VSTOXX. The periods of regional turmoil are identified following De BocK and de Carvalho Filho (2015). At the start of these periods, the VSTOXX is 10 percentage points higher than its average value during the previous 60 days. The three months following the start dates are shaded in the figure. The vertical line at September 2011 denotes the time when the exchange rate floor of 1 euro $=1.20 \mathrm{CHF}$ was introduced by the Swiss National Bank. The vertical line at January 2015 denotes the time when the exchange rate floor was discontinued.

Although international financial institutions and the financial press ${ }^{2}$ have maintained the view that capital inflows were driving the exchange rate of safe haven currencies during the global turmoil, the academic literature on this topic has

2 See, for example, http://www.ft.com/intl/cms/s/0/b504bd8c-e37c-1le0-8f47-00144feabdc0. $\mathrm{html}$ \#axzz2bl1jbZiw and http://www.ft.com/intl/cms/s/0/4ele6178-4695-11e1-89a8-00144feabdc0.html\#axzz2eVAsJdzC 
been rather sparse. ${ }^{3}$ Yet, knowing the drivers of exchange rate movements is essential in order to design the best monetary policy response to a sudden appreciation. This paper aims to contribute to the literature by systematically analyzing the role of capital flows in the movements of a safe haven currency, namely, the CHF. ${ }^{4}$

The empirical relationship between net capital flows and exchange rates has been studied extensively in the literature. However, these studies have generally focused on developing countries, which have been the major recipients of net capital inflows to finance their current account deficits. Depending on the sample and period, some studies have found that certain types of net capital flows comove with the exchange rate. However, very few papers have focused on major currencies or gross capital flows. This paper contributes to the existing literature by shedding some light on the link between the movements of a safe haven currency and different types of capital in- and outflows while controlling for global and regional uncertainty in financial markets.

This paper uses quarterly Swiss balance of payments statistics (BOPS) from the SNB for the period 2000:Q1-2015:Q4. In line with the existing literature on the statistical relationship between capital flows and exchange rates, changes in the log real effective exchange rate (REER) of the CHF are regressed sequentially on various capital flow variables. The only control variables used in these regressions are three dummy variables that control for the SNB's different exchange rate policies during the sample period, as well as the interaction terms between the capital flow and dummy variables. To test alternative drivers for the exchange rate movements, specifications with other explanatory variables are used. These variables capture market uncertainty, e.g., the VIX and VSTOXX, as well as short- and long-term interest rate differentials. Therefore, the empirical setup resembles a horse race between potential drivers of CHF movements. These simple sequential

3 De Carvalho Filho (2015) and Botman, de Carvalho Filho, and Lam (2013) are two exceptions.

4 Although unwinding of carry trade positions is also mentioned as a possible mechanism for exchange rate movements (see, for example, Brunnermeier, Nagel, and Pederson, 2008), this hypothesis is notoriously difficult to test because data of carry trade activity across the globe are unavailable (Galati, Heath, and McGuire, 2007). Studies usually control for observable indicators that would potentially affect or be affected by carry trade activity (HossFELD and MACDONALD, 2015). Therefore, this issue as such is outside the scope of this paper and the focus is solely on capital flows. On the other hand, interest rate differential, another possible determinant of the exchange rate considered in this study, may capture the attractiveness of carry trading.

5 This period represents the longest possible sample for Switzerland's quarterly capital flows data at the time of writing this paper. 
regressions are in the spirit of the ones employed in BRooks et al. (2004), who study the ability of portfolio and foreign direct investment (FDI) flows to track movements in the euro and yen against the dollar.

The empirical analysis shows that the explanatory power of capital flow variables for the movements of the CHF is not always statistically significant-or is economically rather small. This finding indicates that no strong statistical relationship exists between the $\mathrm{CHF}$ and contemporaneous capital flows. By contrast, variables that capture market uncertainty are persistently coincident with exchange rate movements. In other words, movements in the exchange rate co-move with global risk perception, but not necessarily with cross-border investment.

Nevertheless, portfolio investment inflows, particularly inflows to equity securities, have a statistical relationship with the exchange rate in a shorter sample up to 2009:Q1. A one-percentage-point increase in the equity securities inflowGDP ratio is coincident with a 0.23 percent increase in the REER of the CHF during that period. However, the economic relevance of the observed relationship is weak in comparison with earlier findings in the literature for other currencies. Furthermore, portfolio investment inflows to Switzerland have historically constituted a very small fraction of total capital inflows. This relationship disappears when the sample is prolonged, even when the analysis controls for different exchange rate regimes that are implemented by the SNB.

One should be cautious in interpreting these results. First, the analysis does not address the endogeneity problem that contemporaneous and future exchange rates also affect contemporaneous capital flows. It studies only the role of capital flows in explaining the movements of the exchange rate within the same quarter. Second, the analysis cannot reveal a causality relationship between the two variables but merely provides an indication that a co-movement of capital flows and exchange rates might be identified. Furthermore, reverse causality may be another issue. Third, as Switzerland is a financial center with deep markets and as cross-border flows can be denominated in foreign currencies, the possibility of a link between capital flows and the CHF may be weakened. ${ }^{6}$ Fourth, omitted variable bias cannot be excluded. Indeed, a third factor, for example, future output productivity, which the study cannot control for, may be driving the comovement of some types of capital flows and the CHF.

6 A currency breakdown of certain (sub)components of capital flows to and from Switzerland is available. For example, a considerable share of cross-border bank lending flows is denominated in US dollars and euros. 
This paper is structured as follows: the next section elaborates on the theoretical and empirical linkages between capital flows and exchange rates, while Section 3 explains the data used in the statistical analysis. Section 4 presents the empirical findings, and Section 5 concludes.

\section{Theoretical and Empirical Considerations}

What are possible mechanisms through which capital flows affect exchange rates? In a theoretical paper, LARTEY (2008) shows that capital inflows to a small open economy can lead to the appreciation of the real exchange rate, which in turn harms the tradable sector, paving the way for the so-called Dutch Disease. In particular, net capital inflows to finance a current account deficit allow expenditure to exceed income, which generates excess domestic demand for nontradables and leads to a resource allocation from the tradable sector to the nontradable sector (resource movement effect). As a result, the relative price of nontradables increases (a spending effect), and the exchange rate appreciates in real terms.

Thus far, the empirical literature on exchange rates and capital flows has focused on testing this theory with data from developing countries, which have been the major recipients of net capital inflows to finance their current account deficits. Findings from different papers seem to depend on the samples considered and the countries' macroeconomic environments. For example, a higher level of financial development is found to attenuate the appreciation of the exchange rate owing to capital inflows (SABOROwsKi, 2009). Furthermore, the exchange rate policy is found to be a further factor affecting the statistical link between capital flows and the exchange rate (СомBEs et al., 2012).

Overall, the literature to date does not offer a definitive answer regarding the relationship between exchange rates and capital flows, and it mainly focuses on net capital flows and developing countries. However, a few papers have shifted the focus to major currencies; for example, Brooks et al. (2004) study the impact of different types of capital flows on the exchange rate of the US dollar. The motivation for their study is as follows: different types of capital flows are invested for different purposes and in different sectors of the economy, and therefore, the impact of different types of capital flows on the exchange rate may differ. For example, FDI inflows would probably be invested in the production of tradables; thus, they would not necessarily lead to an appreciation of the domestic currency. Another argument why FDI flows would not result in excess demand for the domestic currency is that FDI flows could be used to import machinery and raw materials from abroad, whereas this argument would not hold for portfolio 
or banking flows, which can lead to an asset price bubble and/or credit expansion, respectively. In fact, a few studies, including Brooks et al. (2004), find that net portfolio investment flows lead to real exchange rate appreciation but that net FDI flows have no effect on the real exchange rate. ${ }^{7}$ By contrast, other studies have found that an inflow of FDI can also result in an appreciation of the exchange rate in financially open countries. ${ }^{8}$ Following the literature, the current paper will attempt to pinpoint particular types of capital flows that might affect the $\mathrm{CHF}$ exchange rate more strongly than others.

Furthermore, the literature on safe haven currencies has focused on the attractiveness of carry trading using such currencies but have not controlled for capital flows. Instead, determinants, such as interest rate differentials and financial market size, have previously received attention. Such empirical studies of exchange rate determination in fact have a theoretical background: in MundellFleming model of open economies with flexible exchange rates, capital flows are driven by interest rate differentials, which in turn determine exchange rates. However, the explanatory power of interest rate differentials for exchange rate movements has been found to be rather low in many studies. For example, using data for 52 currencies for 25 years, Нabib And Stracca (2012) find that the safe haven status of a currency is not determined by the interest rate spread, as claimed in the carry trade literature. ${ }^{10}$ By contrast, the net foreign asset position and, to some extent, the stock market size can explain exchange rate behavior during financial stress. Because the net foreign asset position is determined to a large extent by capital in- and outflows, ${ }^{11}$ a link may exist between exchange rate movements and capital flows for safe haven currencies. ${ }^{12}$

7 For example, using a sample of 57 developing countries for the period between 1980 and 2007, Bakardzhieva, Naceur, and Kamar (2010) find that inflows of portfolio investments, foreign borrowing, aid, and income lead to real exchange rate appreciation, while inflows of FDI have no effect on the real exchange rate.

8 For example, using a sample of 109 developing and transition countries during 1990-2003, LARTEY (2011) finds that an increase in FDI inflows does result in an appreciation of the real exchange rate in financially open countries.

9 See Fleming (1962), Mundell (1963), and Dornbusch (1976).

10 This finding is also confirmed in BROOKs et al. (2004), where traditional explanatory variables, such as the short-term interest rate and growth differentials, contribute little in explaining the movement of the US dollar.

11 Asset valuation changes also affect the net foreign asset position, but to a lesser extent.

12 This presumption, however, is challenged by Botman, DE CARvalho, and LAM (2013), who argue that neither capital inflows nor expectations of future monetary policy stance can explain the Japanese yen's safe haven behavior. 
Another consideration involves net versus gross capital flows. In the recently growing literature on capital flows, various studies have shifted the focus from net capital flows to gross capital in- and outflows. For example, KraAy et al. (2005), Lane and Milesi-Ferretti (2007), Broner et al. (2013), Forbes and Warnock (2012), Powell and Tavella (2012), and Avdjiev, McCauley, and SHIN (2015) differentiate between capital flows driven by domestic residents and those driven by foreign residents in their analysis. These papers argue that capital in- and outflows behave differently in the face of global and domestic shocks and carry important informational content on their own. Following this growing literature, the current paper uses an empirical methodology that will reveal whether in- and outflows can affect the CHF differently.

Capital flows to and from Switzerland have been the subject of two recent papers. De Carvalho Filho (2015) and Yeşın (2015) both study capital flows to and from Switzerland. Using the local projections method, DE Carvalho FiLHo (2015) studies the statistical link between capital flows to and from Switzerland and the appreciation of the CHF during the so-called risk-off episodes: he finds that risk-off episodes are associated with real appreciation of the CHF and massive capital inflows, which are driven by lower gross capital outflows by Swiss residents. However, the sample period is too short for a robust statistical analysis and most of the impulse response functions of capital flow variables to a risk-off shock lie within a confidence interval that includes zero over the whole horizon. By contrast, YEşIN (2015) uses a simple statistical method to identify waves of capital flows to and from Switzerland. The analysis shows that Switzerland has not received surges of private capital (aka safe haven) after the financial crisis. Instead, net capital flows have become significantly more volatile because of the lower degree of co-movement of in- and outflows. However, YeşIN (2015) does not empirically analyze the link between capital flows (or capital flow waves) and the CHF. Nevertheless, these two papers challenge the presumption that foreigners have increased their investments in Switzerland during global turmoil and thus exerted appreciation pressure on the CHF. The current paper will complement these two studies by assessing the relative importance of different types of capital flows in explaining the movements of the CHF in separate statistical models. This approach resembles a horse race among various types of capital flows. 


\section{Data}

Data on Switzerland's capital flows are taken from the SNB's BOPS and are based on the BPM6 accounting standard. ${ }^{13}$ They are on a quarterly basis, and they cover the period from 2000:Q1 to 2015:Q4. ${ }^{14}$ The types of capital flows analyzed in this study include gross capital flows and private capital flows, ${ }^{15}$ as well as their major components and subcomponents. In particular, the following capital flow variables are used in the analysis: direct investment, and its subcomponents equity capital, reinvested earnings, and debt instrument flows; portfolio investment, and its subcomponents debt securities and equity securities; other investment, and its subcomponents bank lending and other sectors lending; reserve assets, and its subcomponent foreign currency investment; and derivatives. Table A1 in Appendix A provides the definitions for these capital flow variables. The empirical analysis uses data on both in- and outflows and net flows.

The REER and nominal effective exchange rate (NEER) of the CHF are taken from the Bank for International Settlements (BIS). They are both broad indices, and the REER is weighted by the consumer price index. The empirical analysis uses average values of these two variables in each quarter.

Four different variables are used to capture information on interest rate differentials. First, the long-term interest rate differential between the US and Switzerland is calculated as the yield spread between 10-year US federal government securities and Swiss Confederation 10-year bonds. Second, the long-term interest rate differential between the euro area and Switzerland is calculated as the yield spread between euro area 10-year government bonds and Swiss Confederation

13 In 2014, the Swiss BOPS and international investment position data were aligned with the IMF's Balance of Payments and International Investment Position Manual, Sixth Edition, BPM6 (http://www.imf.org/external/pubs/ft/bop/2007/bopman6.htm). This version of the paper uses Swiss BOPS based on this new accounting standard. An earlier version of this paper used data based on the previous BPM5 accounting standard. The general findings of the statistical analysis are robust to the choice of accounting standard. More information on the change in accounting standards in Switzerland can be found at http://www.snb.ch/en/ iabout/stat/bpm6/id/stat_bpm6_uebersicht.

14 Data on Switzerland's quarterly capital flows based on the BPM6 standard start only in 2000:Q1. Annual data are also available only from 2000 onwards (as of September 2016).

15 Gross capital flows consist of private capital flows and public capital flows. Public capital flows are defined as flows that go to or emanate from the public sector, while private capital flows are defined as the residual. In particular, reserve accumulation by central banks is included in public capital flows. The data on private capital flows used in this study are not available as such from the Swiss BOPS; instead, they are the author's own calculations where all government-related flows are subtracted from gross capital flows. 
10-year bonds, where euro area yields are weighted averages of national government bond yields and where the weights are the nominal outstanding amounts of the government bonds of the respective countries. Two short-term interest rate differential variables are calculated using money market rates in the same manner as explained above.

Two indicators are used in the empirical analysis to capture risk aversion. First, the Chicago Board of Option Exchange's volatility index (VIX) is used to control for global risk aversion. Second, the VSTOXX is used to control for risk aversion in European financial markets. The VIX is the option-implied expected volatility of the S\&P500 index. Thus, it captures the risk aversion and uncertainty in US financial markets, and it is considered to be a proxy for uncertainty in global financial markets. According to the carry trade literature, carry trade flows tend to increase when the VIX is low and tend to collapse when the VIX spikes. Furthermore, recent papers, such as Forbes and WARNOCK (2012) and BRUNo and SHIN (2013), find that fluctuations in global risk factors-measured, for example, by the VIX-are associated with fluctuations in capital flows. ${ }^{16}$ Additionally, the European volatility index, VSTOXX, captures the risk aversion and uncertainty in European financial markets. Figure 1 suggests that the $\mathrm{CHF}$ has tended to appreciate when the VSTOXX exhibits a sudden and steep increase.

Further details on the variables used can be found in Table A2 in Appendix A.

\section{Empirical Findings}

\subsection{Unit Root Tests}

Table 1 presents the results of Augmented Dickey Fuller tests for all variables used in the empirical analysis for the whole sample period. The hypothesis that the log REER and the log NEER do not have a unit root cannot be rejected. ${ }^{17}$ Therefore, the model specification in the next subsection will include differences rather than levels of the exchange rate as the dependent variable. By contrast, all capital flow variables (denoted as ratios to quarterly GDP) are stationary according to the unit root tests. The financial market uncertainty variables, VIX and VSTOXX also do not have a unit root. However, the unit root hypotheses cannot be rejected for three of the four interest rate differential variables.

16 See also Rey (2015) on international capital flows and the VIX.

17 The results do not change when the sample period is shortened to 2000:Q1-2009:Q1 (before the SNB started to intervene in foreign exchange markets) or to 2000:Q1-2011:Q2 (before the introduction of the nominal exchange rate floor). 
Table 1: Unit Root Tests (2000:Q1-2015:Q4)

\begin{tabular}{|c|c|c|c|}
\hline $\ln (\mathrm{REER})$ & -1.24 & & \\
\hline$\Delta \ln (\mathrm{REER})$ & $-5.87^{* * *}$ & & \\
\hline $\ln (\mathrm{NEER})$ & -0.25 & & \\
\hline$\Delta \ln (\mathrm{NEER})$ & $-5.90^{* * *}$ & & \\
\hline longrun $\mathrm{r}(\mathrm{US}-\mathrm{CH})$ & -1.89 & & \\
\hline longrun $\mathrm{r}(\mathrm{EMU}-\mathrm{CH})$ & -2.16 & & \\
\hline shortrun r(US-CH) & $-2.81^{*}$ & & \\
\hline shortrun r(EMU-CH) & -2.14 & & \\
\hline VIX & $-3.16^{* *}$ & & \\
\hline \multirow[t]{2}{*}{ VSTOXX } & $-3.22^{* *}$ & & \\
\hline & inflows & outflows & netflows \\
\hline Gross capital flows & $-6.18^{* * *}$ & $-5.92^{* * *}$ & $-6.34^{* * *}$ \\
\hline Private capital flows & $-6.12^{* * *}$ & $-5.17^{* * *}$ & $-4.98^{* * *}$ \\
\hline Direct investment & $-3.27^{* *}$ & $-3.69^{* * *}$ & $-5.24^{* * *}$ \\
\hline Equity capital & $-4.06^{* * *}$ & $-4.54^{* * *}$ & $-5.15^{* * *}$ \\
\hline Reinvested earnings & $-4.72^{* * *}$ & $-2.93^{* *}$ & $-2.96^{* *}$ \\
\hline Debt instruments & $-4.92^{* * *}$ & $-5.43^{* * *}$ & $-7.84^{* * *}$ \\
\hline Portfolio investment & $-5.04^{* * *}$ & $-4.85^{* * *}$ & $-5.25^{* * *}$ \\
\hline Debt securities & $-5.10^{* * *}$ & $-4.84^{* * *}$ & $-4.73^{* * *}$ \\
\hline Equity securities & $-4.47^{* * *}$ & $-4.25^{* * *}$ & $-4.20^{* * *}$ \\
\hline Other investment & $-6.56^{* * *}$ & $-5.51^{* * *}$ & $-5.68^{* * *}$ \\
\hline Bank lending & $-7.00^{* * *}$ & $-6.31^{* * *}$ & $-6.57^{* * *}$ \\
\hline Other sectors lending & $-4.79^{* * *}$ & $-4.36^{* * *}$ & $-5.32^{* * *}$ \\
\hline Reserve assets & & $-5.94^{* * *}$ & \\
\hline Foreign currency investment & & $-6.07^{* * *}$ & \\
\hline Derivatives & & & $-3.38^{* *}$ \\
\hline
\end{tabular}

Notes: The table lists results of Augmented Dickey-Fuller tests using a constant and 1 lag based on the null hypothesis that there is a unit root. ${ }^{* * *}$ denotes statistical significance at $1 \%,{ }^{* *}$ denotes significance at $5 \%$, and ${ }^{*}$ denotes significance at $10 \%$. 


\subsection{Bivariate Results: REER}

The model specification used in this section is in the spirit of BROокs et al. (2004), who analyze whether net portfolio and FDI inflows to the US from the euro area and Japan can track movements of the euro and yen against the dollar in bivariate specifications. However, data on bilateral capital flows are not available for Switzerland. Therefore, aggregate capital flows over all countries and the REER of the CHF are used in the specification in this paper. In some robustness tests, the NEER is used instead of the REER. Furthermore, all capital flow variables are normalized by quarterly GDP, and both gross and net flows are used as explanatory variables. These two features make the current study's methodology different from that in Brooks et al. (2004).

The relative importance of different types of capital flows in explaining the movements of the CHF are assessed using separate statistical models. In particular, the first-order difference in the log REER is regressed sequentially on various types of capital flows as well as other possible determinants of the exchange rate, such as interest rate differentials and uncertainty in global and regional financial markets. In brief, these bivariate regressions resemble a horse race among the possible determinants of the exchange rate where some are traditional variables used in the literature and others are alternative explanations for exchange rate movements, such as capital flows and uncertainty in financial markets. The estimation method employed is ordinary least squares. The findings are robust to the use of the Newey-West estimator, which corrects for heteroskedasticity and autocorrelation in the error terms.

In line with the literature, the short- and long-term interest rate differentials between the CHF and the euro and between the CHF and the US dollar are used in the empirical analysis. These variables capture the attractiveness of the CHF as a funding currency owing to the Uncovered Interest Rate Parity (UIP) gap. ${ }^{18}$

To estimate the statistical link between uncertainty in financial markets and CHF movements, two other explanatory variables are considered in the bivariate analysis, namely, the Chicago Board of Option Exchange's VIX and the European volatility index, VSTOXX. These two variables are inspired by Figure 1.

18 Other variables could be included in the empirical setup; however, in the literature, there are no theoretical models or empirical results that pinpoint all the explanatory variables. Moreover, often, empirical models do not support the implications of theoretical models. For example, MANCINI Griffoli et al. (2015) study the determinants of bilateral real exchange rates of the $\mathrm{CHF}$ in a panel setting and find that relative productivity cannot explain the movements of the CHF, which contradicts the Balassa-Samuelson effect. 
Table 2 presents the results of bivariate regressions using data from 2000:Q1 to 2015:Q4, where the estimated coefficients of the explanatory variables and the fit of the regressions are listed. The table first lists the results for interest rate differentials and uncertainty in financial markets and then provides the results for capital flow variables. Overall, the R-squares are rather small as it would be expected when the dependent variable is changes in the exchange rate in a bivariate regression model.

The table shows that the VIX, VSTOXX and short-term interest rate differential between the US dollar and the CHF have some explanatory power in explaining CHF movements. For example, a one-percentage-point increase in the VIX is coincident with a 0.07 percent appreciation of the CHF. By contrast, the coefficients for the interest rate differentials are all negative as expected, but in three out of four cases, they are statistically insignificant. Thus, interest rate differentials do not appear to be statistically significant in explaining the movements of the CHF in a bivariate regression during this sample period. The insignificance of the coefficients may be due to the extremely low and stable interest rate environment after the financial crisis. The zero lower bound may be another factor to consider. ${ }^{19}$

Regarding the link between capital flows and the CHF, the coefficients of the capital inflow variables are expected to be positive, and the coefficients of the outflow and net flow variables are expected to be negative. That is, an increase in inflows to Switzerland would be coincident with an appreciation of the CHF, whereas an increase in outflows from Switzerland would be coincident with a depreciation of the CHF. Similarly, an increase in net flows is expected to be coincident with a depreciation of the CHF, because positive net flow values indicate net outflows by definition.

Table 2 shows that none of the inflow variables except other sectors lending has a statistically significant coefficient. Furthermore, the estimated coefficient of other sectors lending is negative, which is counterintuitive. Overall, capital inflows to Switzerland do not appear to be coincident with CHF appreciation.

However, some capital outflow variables exhibit a statistically significant coefficient with the expected negative sign. In particular, outflows of private capital, debt instruments, other investment, and bank lending are coincident with $\mathrm{CHF}$ depreciations. For example, a one-percentage-point increase in the private

19 Multivariate regressions or other sample periods can, of course, reverse this finding. However, the result is robust to using real interest rate differentials instead of nominal interest rate differentials as an explanatory variable. 
Table 2: Bivariate Regressions: REER (2000:Q1-2015:Q4)

\begin{tabular}{|c|c|c|c|c|c|c|}
\hline & coeff & $\mathrm{R}^{2}$ & & & & \\
\hline longrun r(US-CH) & -.009 & 0.04 & & & & \\
\hline longrun r(EMU-CH) & .000 & 0.00 & & & & \\
\hline shortrun r(US-CH) & $-.004^{*}$ & 0.06 & & & & \\
\hline shortrun $\mathrm{r}(\mathrm{EMU}-\mathrm{CH})$ & .000 & 0.00 & & & & \\
\hline VIX / 100 & $.073^{* *}$ & 0.07 & & & & \\
\hline \multirow[t]{3}{*}{ VSTOXX / 100} & $.057^{*}$ & 0.05 & & & & \\
\hline & \multicolumn{2}{|c|}{ inflows } & \multicolumn{2}{|c|}{ outflows } & \multicolumn{2}{|c|}{ netflows } \\
\hline & coeff & $\mathrm{R}^{2}$ & coeff & $\mathrm{R}^{2}$ & coeff & $\mathrm{R}^{2}$ \\
\hline Gross capital flows & -.009 & 0.03 & -.008 & 0.03 & -.001 & 0.00 \\
\hline Private capital flows & -.008 & 0.03 & $-.012^{* *}$ & 0.06 & $-.036^{* *}$ & 0.08 \\
\hline Direct investment & -.015 & 0.00 & -.041 & 0.02 & -.030 & 0.01 \\
\hline Equity capital & -.016 & 0.00 & .019 & 0.00 & .025 & 0.01 \\
\hline Reinvested earnings & -.012 & 0.00 & -.105 & 0.02 & -.067 & 0.01 \\
\hline Debt instruments & -.025 & 0.00 & $-.142^{* *}$ & 0.07 & -.073 & 0.03 \\
\hline Portfolio investment & .057 & 0.01 & .012 & 0.00 & .004 & 0.00 \\
\hline Debt securities & .086 & 0.01 & -.004 & 0.00 & -.013 & 0.00 \\
\hline Equity securities & .012 & 0.00 & .120 & 0.04 & .056 & 0.02 \\
\hline Other investment & -.009 & 0.03 & $-.013^{* *}$ & 0.07 & -.021 & 0.03 \\
\hline Bank lending & -.007 & 0.02 & $-.014^{* *}$ & 0.07 & $-.038^{* *}$ & 0.08 \\
\hline Other sectors lending & $-.087^{*}$ & 0.05 & -.039 & 0.02 & .015 & 0.00 \\
\hline Reserve assets & & & $.032^{*}$ & 0.06 & & \\
\hline Foreign currency investment & & & $.031^{*}$ & 0.05 & & \\
\hline Derivatives & & & & & $-1.421^{* *}$ & 0.09 \\
\hline
\end{tabular}

Notes: The dependent variable is the first difference of the logarithm of the REER. The table summarizes the results of sequential bivariate regressions of the dependent variable on the contemporaneous values of various independent variables. The estimation method is ordinary least squares. ${ }^{* * *}$ denotes statistical significance at $1 \%,{ }^{* *}$ denotes significance at $5 \%$, and ${ }^{*}$ denotes significance at $10 \%$. 
capital outflow-GDP ratio is associated with a 0.012 percent depreciation of the $\mathrm{CHF}$ in real trade-weighted terms. However, in contrast to the prior results, the coefficients of reserve asset outflows and foreign currency investment outflows are positive and statistically significant. This result can be explained by the special features of the sample period, and it may merely be due to reverse causality. Namely, between 2009:Q2 and 2010:Q2 and between 2011:Q3 and 2014:Q4, the SNB heavily intervened in foreign exchange markets with the aim of halting (and reversing) the appreciation of the CHF amid the European sovereign debt crises. At the end of both episodes, however, the exchange rate was allowed to float freely and appreciated significantly. Therefore, a robustness check with a shorter sample period excluding these intervention periods is warranted for these two coefficients in particular.

Next, the coefficients of net capital outflow variables are considered. Table 2 shows that net private capital flows and net bank lending flows are coincident with exchange rate depreciations. The coefficients are statistically significant with the expected signs. A one-percentage-point increase in the net private capital flow-GDP ratio is coincident with a 0.036 percent decline in the CHF in real trade-weighted terms.

Net derivatives flows show the economically largest co-movement with the CHF. A serious drawback of this finding, however, is that the data on this subcomponent starts only in 2005:Q1, making the sample period fairly short. Therefore, this finding should be interpreted with caution. Another caveat of this finding is the difficulty of interpreting the flows of derivatives and structured products. The nature of financial derivatives as instruments through which risk is traded in its own right differentiates them from other types of investment, such as FDI. While all positions in this asset/liability class are normally registered in a country's net foreign assets, only a part of the outstanding derivatives will ultimately appear in net capital flows because only some of these positions will require upfront charges and/or will be executed at maturity to initiate a capital flow. Furthermore, transactions involving financial derivatives may arise at inception, on secondary markets, with ongoing servicing (such as for margin payments), and at settlement. Thus, a positive net flow of derivatives is difficult to interpret economically. A flow of derivatives does not necessarily translate into an increase or decrease in foreign assets or liabilities, and a positive net flow of derivatives simply means that Swiss residents pay foreign counterparties in net terms for transactions involving financial derivatives.

Since the sample period includes the times when the CHF was not freely floating, Table 3 presents a robustness check of the results in Table 2 with a shorter sample from 2000:Q1 to 2009:Q1 only, the period before the SNB started 
Table 3: Bivariate Regressions: REER (2000:Q1-2009:Q1)

\begin{tabular}{|c|c|c|c|c|c|c|}
\hline & coeff & $\mathrm{R}^{2}$ & & & & \\
\hline longrun $\mathrm{r}(\mathrm{US}-\mathrm{CH})$ & $-.015^{* * *}$ & 0.21 & & & & \\
\hline longrun r(EMU-CH) & .022 & 0.06 & & & & \\
\hline shortrun r(US-CH) & $-.005^{* *}$ & 0.15 & & & & \\
\hline shortrun r(EMU-CH) & .008 & 0.03 & & & & \\
\hline VIX / 100 & $.103^{* * *}$ & 0.33 & & & & \\
\hline \multirow[t]{3}{*}{ VSTOXX / 100} & $.081^{* * *}$ & 0.26 & & & & \\
\hline & \multicolumn{2}{|c|}{ inflows } & \multicolumn{2}{|c|}{ outflows } & \multicolumn{2}{|c|}{ netflows } \\
\hline & coeff & $\mathrm{R}^{2}$ & coeff & $\mathrm{R}^{2}$ & & $\mathrm{R}^{2}$ \\
\hline Gross capital flows & $-.011^{* *}$ & 0.14 & $-.012^{* * *}$ & 0.18 & $-.055^{* *}$ & 0.15 \\
\hline Private capital flows & $-.011^{* *}$ & 0.12 & $-.012^{* * *}$ & 0.18 & $-.051^{* * *}$ & 0.17 \\
\hline Direct investment & -.060 & 0.04 & -.034 & 0.03 & -.005 & 0.00 \\
\hline Equity capital & -.046 & 0.01 & .024 & 0.01 & .044 & 0.02 \\
\hline Reinvested earnings & -.089 & 0.02 & $-.183^{* *}$ & 0.14 & -.090 & 0.05 \\
\hline Debt instruments & -.151 & 0.04 & -.079 & 0.03 & -.015 & 0.00 \\
\hline Portfolio investment & $.243^{* * *}$ & 0.19 & -.023 & 0.02 & -.038 & 0.06 \\
\hline Debt securities & .240 & 0.02 & -.027 & 0.01 & -.029 & 0.02 \\
\hline Equity securities & $.232^{* *}$ & 0.17 & -.029 & 0.00 & $-.106^{*}$ & 0.09 \\
\hline Other investment & $-.012^{* *}$ & 0.14 & $-.013^{* * *}$ & 0.18 & -.017 & 0.02 \\
\hline Bank lending & $-.011^{* *}$ & 0.13 & $-.013^{* *}$ & 0.15 & -.010 & 0.01 \\
\hline Other sectors lending & -.058 & 0.05 & $-.061^{*}$ & 0.10 & -.081 & 0.06 \\
\hline Reserve assets & & & .176 & 0.06 & & \\
\hline Foreign currency investment & & & .323 & 0.03 & & \\
\hline Derivatives & & & & & $-1.711^{* * *}$ & 0.33 \\
\hline
\end{tabular}

Notes: The table summarizes the results of sequential bivariate regressions of the first difference of the logarithm of the REER on the contemporaneous values of various independent variables. The estimation method is ordinary least squares. ${ }^{* * *}$ denotes statistical significance at $1 \%$, ${ }^{* *}$ denotes significance at $5 \%$, and ${ }^{*}$ denotes significance at $10 \%$. 
intervening in foreign exchange markets. ${ }^{20} \mathrm{~A}$ few interesting observations can be made. First, the regression fit of the bivariate models substantially improves when the independent variable is the interest rate differential between the US and Switzerland or market uncertainty. The interest rate differential between the euro area and Switzerland remains statistically insignificant. Moreover, the statistical significance and economic relevance are significantly improved for these variables.

Table 3 also shows that the fit of the regressions with capital flow variables as the independent variables significantly improves in many cases and that the statistical significance is stronger for a greater number of capital flow variables. For example, for the short-period sample, several capital inflow variables are now coincident with the exchange rate, although many of them have the incorrect sign. ${ }^{21}$ Only portfolio investment inflows and its subcomponent equity securities inflows are associated with CHF appreciations. Specifically, one-percentage-point increase in the equity securities inflow-GDP ratio is associated with a 0.23 percent appreciation of the $\mathrm{CHF}$ in real trade-weighted terms during 2000:Q1-2009:Q1. Among the capital outflow variables, gross capital outflows and other sectors lending outflows, as well as outflows of private capital, reinvested earnings, other investment, and bank lending, are now statistically significant. By contrast, among the net flow variables, only gross capital flows, net private capital flows and equity securities outflows are coincident with the REER of the CHF. A one-percentage-point increase in the net private capital flow-GDP ratio is associated with a 0.05 percent depreciation of the CHF in real tradeweighted terms during 2000:Q1-2009:Q1. Some of the diverging results shown in Tables 2 and 3 hint at the possibility that after the financial crisis the empirical relationship between capital flows and the $\mathrm{CHF}$ may have changed considerably.

To account for the different exchange rate policies pursued by the SNB during the whole sample period, three different dummies are introduced into the bivariate models. Dummy1 takes the value 1 between 2009:Q2 and 2010:Q2 to control for the exchange rate interventions by the SNB during that period. ${ }^{22}$ Dummy2

20 The findings do not change significantly when the sample is shortened to 2000:Q1-2011:Q2, the period before the introduction of the exchange rate floor.

21 Notably, other investment inflows and subcomponent bank lending inflows exhibit statistically significant coefficients with counterintuitive signs. One driver of this finding may be the strong correlation between the inflows and outflows. As a financial center, Switzerland intermediates a very high fraction of banking inflows to the rest of the world as banking outflows.

22 In fact, the SNB started to intervene in mid-March 2009 and stopped its interventions in mid-June 2010. Because of the quarterly nature of the capital flow data, however, the dummies here are chosen not to match the end of quarter situation but rather to indicate whether there were interventions in the exchange rate markets for the majority of the quarter. As the 
Table 4: REER Regressions Controlling for Exchange Rate Regimes (2000:Q1-2015:Q4)

\begin{tabular}{|c|c|c|c|c|c|c|}
\hline & coeff & $\mathrm{R}^{2}$ & & & & \\
\hline longrun r(US-CH) & -.009 & 0.19 & & & & \\
\hline longrun r(EMU-CH) & -.008 & 0.18 & & & & \\
\hline shortrun r(US-CH) & $-.006^{* *}$ & 0.23 & & & & \\
\hline shortrun r(EMU-CH) & -.004 & 0.17 & & & & \\
\hline VIX / 100 & $.069^{* *}$ & 0.22 & & & & \\
\hline \multirow[t]{3}{*}{ VSTOXX / 100} & $.052^{*}$ & 0.20 & & & & \\
\hline & \multicolumn{2}{|c|}{ inflows } & \multicolumn{2}{|c|}{ outflows } & \multicolumn{2}{|c|}{ netflows } \\
\hline & coeff & $\mathrm{R}^{2}$ & coeff & $\mathrm{R}^{2}$ & coeff & $\mathrm{R}^{2}$ \\
\hline Gross capital flows & -.010 & 0.20 & -.009 & 0.20 & -.011 & 0.16 \\
\hline Private capital flows & -.009 & 0.19 & $-.013^{* *}$ & 0.23 & $-.070^{* * *}$ & 0.30 \\
\hline Direct investment & -.023 & 0.17 & -.059 & 0.20 & -.036 & 0.18 \\
\hline Equity capital & .005 & 0.16 & .014 & 0.16 & .011 & 0.16 \\
\hline Reinvested earnings & -.058 & 0.16 & -.136 & 0.19 & -.067 & 0.17 \\
\hline Debt instruments & -.048 & 0.17 & $-.152^{* *}$ & 0.24 & -.070 & 0.19 \\
\hline Portfolio investment & .039 & 0.16 & .021 & 0.17 & .012 & 0.16 \\
\hline Debt securities & -.005 & 0.16 & .002 & 0.16 & .002 & 0.16 \\
\hline Equity securities & .055 & 0.17 & .132 & 0.20 & .046 & 0.17 \\
\hline Other investment & -.010 & 0.20 & $-.014^{* *}$ & 0.23 & $-.034^{*}$ & 0.21 \\
\hline Bank lending & -.008 & 0.18 & $-.014^{* *}$ & 0.22 & $-.052^{* *}$ & 0.24 \\
\hline Other sectors lending & $-.096^{*}$ & 0.22 & $-.064^{*}$ & 0.21 & -.025 & 0.16 \\
\hline Reserve assets & & & $.09^{* * *}$ & 0.28 & & \\
\hline Foreign currency investment & & & $.086^{* * *}$ & 0.27 & & \\
\hline Derivatives & & & & & $-1.772^{* *}$ & 0.31 \\
\hline
\end{tabular}

Notes: The table summarizes the results of sequential multivariate regressions of the first difference of the logarithm of the REER on the contemporaneous values of various independent variables and three dummy variables that control for different exchange rate policies. The estimation method is ordinary least squares. ${ }^{* * *}$ denotes statistical significance at $1 \%$, ${ }^{* *}$ denotes significance at $5 \%$, and ${ }^{*}$ denotes significance at $10 \%$. 
takes the value 1 between 2011:Q3 and 2014:Q4 to control for the SNB's interventions to sustain the exchange rate floor of 1 euro $=1.20 \mathrm{CHF}^{23}$ Dummy 3 takes the value 1 between 2010:Q3 and 2011:Q2 to control for the period of no SNB intervention and the strong appreciation of the CHF amid the European sovereign debt crisis. Furthermore, interaction terms between the dummy variables and the various types of capital flows are considered to capture any nonlinearity between capital flows and exchange rates that arose during these periods with different exchange rate regimes.

Table 4 summarizes the results for the whole sample period when the dummy variables are included in the specification. In comparison with that in Table 2, the fit of the regressions is significantly higher in Table 4. However, controlling for the exchange rate regime for the long-period sample does not lead to results similar to those obtained for the short-period sample. This finding suggests that the relationship between capital flows and the CHF became more complex after 2009.

\subsection{Bivariate Results: NEER}

This section repeats the bivariate analysis using the NEER instead of the REER as the dependent variable. The results are very similar to those presented in the previous subsection. In other words, using the NEER or REER as the dependent variable does not influence the findings. Capital flows and CHF movements (in nominal or real terms) do not co-move strongly, whereas variables that capture market uncertainty continue to have statistically significant and economically larger coefficients.

Table 5 lists the regression results for the long-period sample, where changes in the NEER are sequentially regressed on various explanatory variables. Table 6 lists the results for the short-period sample until 2009:Q1. Table 5 shows that the VIX, VSTOXX and short-term interest rate differential between the US dollar and the CHF have some explanatory power in explaining CHF movements. For example, a one-percentage-point increase in the VIX is coincident with a 0.07

financial flow variables indicate the flows during the whole quarter, this approach is in line with the spirit of the statistical analysis. Therefore, Dummyl takes the value 0 in 2009:Q1 and 1 in 2010:Q2. However, the estimation results are robust to changed definitions of the dummy variables to match the end-of-quarter situation.

23 Altermatt and Baeriswyl (2015) study the effect of the monetary base expansion in Switzerland on the balance sheets of domestic banks, while AuER (2015) studies banks' international demand for the CHF during this period. 
Table 5: Bivariate Regressions: NEER (2000:Q1-2015:Q4)

\begin{tabular}{|c|c|c|c|c|c|c|}
\hline & coeff & $\mathrm{R}^{2}$ & & & & \\
\hline longrun r(US-CH) & $-.01^{*}$ & 0.05 & & & & \\
\hline longrun r(EMU-CH) & .003 & 0.00 & & & & \\
\hline shortrun r(US-CH) & $-.005^{* *}$ & 0.07 & & & & \\
\hline shortrun r(EMU-CH) & .000 & 0.00 & & & & \\
\hline VIX / 100 & $.073^{* *}$ & 0.07 & & & & \\
\hline \multirow[t]{3}{*}{ VSTOXX / 100} & $.059 *$ & 0.06 & & & & \\
\hline & \multicolumn{2}{|c|}{ inflows } & \multicolumn{2}{|c|}{ outflows } & \multicolumn{2}{|c|}{ netflows } \\
\hline & coeff & $\mathrm{R}^{2}$ & coeff & $\mathrm{R}^{2}$ & coeff & $\mathrm{R}^{2}$ \\
\hline Gross capital flows & -.007 & 0.02 & -.007 & 0.02 & -.005 & 0.00 \\
\hline Private capital flows & -.006 & 0.02 & $-.011^{*}$ & 0.05 & $-.039^{* *}$ & 0.10 \\
\hline Direct investment & -.017 & 0.00 & -.039 & 0.02 & -.026 & 0.01 \\
\hline Equity capital & -.024 & 0.00 & .017 & 0.00 & .026 & 0.01 \\
\hline Reinvested earnings & -.015 & 0.00 & -.109 & 0.02 & -.069 & 0.01 \\
\hline Debt instruments & -.023 & 0.00 & $-.129^{*}$ & 0.06 & -.066 & 0.02 \\
\hline Portfolio investment & .028 & 0.00 & .006 & 0.00 & .002 & 0.00 \\
\hline Debt securities & .057 & 0.00 & -.010 & 0.00 & -.015 & 0.00 \\
\hline Equity securities & -.008 & 0.00 & .108 & 0.03 & .057 & 0.02 \\
\hline Other investment & -.007 & 0.02 & $-.012^{*}$ & 0.05 & -.023 & 0.04 \\
\hline Bank lending & -.005 & 0.01 & $-.012^{*}$ & 0.05 & $-.041^{* *}$ & 0.09 \\
\hline Other sectors lending & -.078 & 0.04 & -.037 & 0.02 & .009 & 0.00 \\
\hline Reserve assets & & & $.033^{*}$ & 0.06 & & \\
\hline Foreign currency investment & & & $.032^{*}$ & 0.05 & & \\
\hline Derivatives & & & & & $-1.572^{* *}$ & 0.11 \\
\hline
\end{tabular}

Notes: The table summarizes the results of sequential bivariate regressions of the first difference of the logarithm of the NEER on the contemporaneous values of various independent variables. The estimation method is ordinary least squares. ${ }^{* *}$ denotes statistical significance at $1 \%,{ }^{* *}$ denotes significance at $5 \%$, and ${ }^{*}$ denotes significance at $10 \%$. 
Table 6: Bivariate Regressions: NEER (2000:Q1-2009:Q1)

\begin{tabular}{|c|c|c|c|c|c|c|}
\hline & coeff & $\mathrm{R}^{2}$ & & & & \\
\hline longrun $\mathrm{r}(\mathrm{US}-\mathrm{CH})$ & $-.016^{* * *}$ & 0.25 & & & & \\
\hline longrun $\mathrm{r}(\mathrm{EMU}-\mathrm{CH})$ & .022 & 0.07 & & & & \\
\hline shortrun r(US-CH) & $-.005^{* * *}$ & 0.17 & & & & \\
\hline shortrun r(EMU-CH) & .007 & 0.02 & & & & \\
\hline VIX / 100 & $.102^{* * *}$ & 0.35 & & & & \\
\hline \multirow[t]{3}{*}{ VSTOXX / 100} & $.081^{* * *}$ & 0.29 & & & & \\
\hline & \multicolumn{2}{|c|}{ inflows } & \multicolumn{2}{|c|}{ outflows } & \multicolumn{2}{|c|}{ netflows } \\
\hline & coeff & $\mathrm{R}^{2}$ & & $\mathrm{R}^{2}$ & coeff & $\mathrm{R}^{2}$ \\
\hline Gross capital flows & $-.009^{* * *}$ & 0.10 & $-.011^{* * *}$ & 0.15 & $-.058^{* * *}$ & 0.18 \\
\hline Private capital flows & $-.009^{* * *}$ & 0.09 & $-.011^{* * *}$ & 0.15 & $-.055^{* * *}$ & 0.22 \\
\hline Direct investment & -.059 & 0.05 & -.030 & 0.02 & -.002 & 0.00 \\
\hline Equity capital & -.050 & 0.01 & .019 & 0.01 & .039 & 0.02 \\
\hline Reinvested earnings & -.083 & 0.02 & $-.181^{* * *}$ & 0.15 & $-.091^{*}$ & 0.06 \\
\hline Debt instruments & -.146 & 0.05 & -.048 & 0.01 & .006 & 0.00 \\
\hline Portfolio investment & $.199^{*}$ & 0.14 & -.022 & 0.02 & -.034 & 0.05 \\
\hline Debt securities & .222 & 0.02 & -.026 & 0.02 & -.028 & 0.02 \\
\hline Equity securities & $.187^{* *}$ & 0.12 & -.031 & 0.00 & -.090 & 0.07 \\
\hline Other investment & $-.009^{* * *}$ & 0.10 & $-.011^{* * *}$ & 0.15 & -.022 & 0.05 \\
\hline Bank lending & $-.009^{* * *}$ & 0.09 & $-.011^{* * *}$ & 0.12 & -.016 & 0.02 \\
\hline Other sectors lending & -.038 & 0.02 & $-.053^{* *}$ & 0.08 & $-.090^{*}$ & 0.08 \\
\hline Reserve assets & & & $.192^{* * *}$ & 0.08 & & \\
\hline Foreign currency investment & & & $.415^{* * *}$ & 0.05 & & \\
\hline Derivatives & & & & & $-1.705^{* * *}$ & 0.36 \\
\hline
\end{tabular}

Notes: The table summarizes the results of sequential bivariate regressions of the first difference of the logarithm of the NEER on the contemporaneous values of various independent variables. The estimation method is ordinary least squares. ${ }^{* * *}$ denotes statistical significance at $1 \%$, ${ }^{* *}$ denotes significance at $5 \%$, and $*$ denotes significance at $10 \%$. 
percent appreciation of the NEER of the CHF. By contrast, long-term interest rate differentials are statistically insignificant, confirming the findings in Table 2. Table 5 also shows that, overall, capital inflows to Switzerland do not appear to be coincident with a nominal appreciation of the CHF in trade-weighted terms. Among the outflow variables, only private capital outflows and other investment outflows (particularly bank lending outflows) are coincident with a nominal depreciation of the CHF. Similar to the findings in the previous section, a onepercentage-point increase in the net private capital flow-GDP ratio is coincident with a 0.04 percent decrease in the CHF.

Regarding the short-period sample results, Table 6 confirms the observations made in Table 3. After 2009, the relationship between capital flows and the CHF seems to have weakened. Controlling for the different exchange rate policies implemented by the SNB does not change the results. For space constraints, those regression results are not presented here.

Bivariate analyses agree that the VIX is persistently coincident with the movements of the CHF. Multivariate analyses with all explanatory variables also confirm this finding. The coefficient of the VIX remains statistically significant in each empirical model, whereas none of the coefficients of the capital flow variables is found to be significant. Due to space constraints, these results are not shown here.

\subsection{Comparison with Other Currencies}

This section extends the bivariate analysis to eight other currencies: the Brazilian real, British Pound, euro, Indian rupee, Japanese yen, South African rand, Turkish lira, and US dollar. The inclusion of currencies from advanced and emerging market economies allows for comparisons with the results for the CHF.

Data on capital flows for these countries are taken from the IMF BOPS. To have a longer sample period, data from the BPM5 and BPM6 accounting standards are merged in the following way: data for 2000:Q1-2004:Q4 are based on the BPM5 standard, and data for 2005:Q1-2015:Q4 are based on the BPM6 accounting standard. Only the major components of capital flow series are used in the cross-country analysis because data on other components are typically unavailable. Furthermore, for all countries except Switzerland, gross capital inflows and private capital inflows are identical, and private capital outflow series are obtained by deducting reserves from gross capital outflows. ${ }^{24}$

24 Although this is a less rigorous estimate of private capital flows, the results are expected to be robust 
Data on the NEER and REER are taken from the BIS; they are broad based indices, and in the case of the REER, they are weighted by consumer prices. The interest rate differentials are calculated by using data from the IMF's IFS database.

Table 7 presents the results for the REER regressions where interest rate differentials and financial market uncertainty are used as explanatory variables.

A few interesting observations can be made. Market uncertainty variables, particularly the VIX, seem to have significant explanatory power for various exchange rates. Only the euro and South African rand are not coincident with market uncertainty variables. The VSTOXX is coincident with most of the currencies. Interestingly, the estimated coefficients are negative for most emerging market economies, such as Brazil and India, and positive for Switzerland, Japan and the US. This finding supports the view that safe haven currencies appreciate with increased financial market uncertainty. This relationship is particularly strong for the Japanese yen: a one-percentage-point increase in the VIX is associated with a 0.28 percent increase in the yen, about four times larger than that in the CHF. By contrast, a one-percentage-point increase in the VIX is associated with a 0.31 percent decline in the Brazilian real and a 0.17 percent decline in the Turkish lira. This finding confirms the view that emerging markets' currencies are vulnerable in times of global financial uncertainty.

Table 7 also indicates that long-term interest rate differentials do not seem to be coincident with exchange rate movements for most currencies. In fact, when the coefficient is statistically significant, it is positive, as in the case for the Brazilian real and British pound. This result is contrary to economic intuition. Furthermore, the short-term interest rate differential with the US is statistically significant and negative for the CHF, euro, and South African rand, whereas the short-term interest rate differential with the euro area is coincident with only the South African rand.

Next, Table 8 presents the results for the REER regressions in which capital flow variables are used as explanatory variables. At a first glance, no general pattern applicable to all countries that links exchange rate movements with any capital flow series can be observed. In general, gross capital inflows, and particularly portfolio investment inflows, are coincident with increases in the exchange rates of emerging market economies. By contrast, advanced economies do not show such a relationship. Direct investment inflows are not coincident with exchange rate movements. Again, this finding is consistent with the literature on emerging market economies.

The results of the regressions with capital outflow series as the explanatory variables yield to some counterintuitive findings. For example, gross capital outflows from emerging market economies are coincident with an appreciation of 
Table 7: Bivariate Regressions: REER (2000:Q1-2015:Q4)

\begin{tabular}{|l|cc|cc|cc|}
\cline { 2 - 7 } \multicolumn{1}{c|}{} & \multicolumn{2}{c|}{ VIX/100 } & \multicolumn{2}{c|}{ VSTOXX / 100 } & \multicolumn{2}{c|}{ longrun r (US - country) } \\
\multicolumn{1}{c|}{ coeff } & $\mathrm{R}^{2}$ & coeff & $\mathrm{R}^{2}$ & coeff & $\mathrm{R}^{2}$ \\
\hline BRA & $-.306^{* * *}$ & 0.13 & $-.315^{* * *}$ & 0.17 & $.019^{* * *}$ & 0.22 \\
IND & $-.091^{* *}$ & 0.09 & $-.080^{* *}$ & 0.09 & .000 & 0.00 \\
TUR & $-.171^{*}$ & 0.05 & -.128 & 0.03 & .003 & 0.00 \\
ZAF & -.053 & 0.01 & .006 & 0.00 & .001 & 0.00 \\
\hline CHE & $.073^{* *}$ & 0.07 & $.057^{*}$ & 0.05 & -.009 & 0.04 \\
EMU & .017 & 0.00 & .033 & 0.01 & -.004 & 0.02 \\
GBR & $-.117^{* * *}$ & 0.16 & $-.073^{* *}$ & 0.08 & $.018^{* *}$ & 0.10 \\
JPN & $.282^{* * *}$ & 0.29 & $.228^{* * *}$ & 0.24 & -.003 & 0.00 \\
USA & $.075^{* *}$ & 0.07 & $.053^{*}$ & 0.05 & - & \\
\hline
\end{tabular}

\begin{tabular}{|l|cc|cc|cc|}
\cline { 2 - 7 } \multicolumn{1}{c|}{} & \multicolumn{2}{c|}{\begin{tabular}{c} 
longrun $\mathrm{r}$ \\
\multicolumn{1}{c|}{}
\end{tabular}} & \multicolumn{2}{c|}{$\begin{array}{c}\text { shortrun } \mathrm{r} \\
\text { (EMU - country) }\end{array}$} & \multicolumn{2}{c|}{$\begin{array}{c}\text { shortrun } \mathrm{r} \\
\text { (US - country) }\end{array}$} \\
\hline BRA & $.013^{* *}$ & 0.16 & -.001 & 0.00 & -.002 & 0.02 \\
IND & -.003 & 0.02 & .001 & 0.02 & .000 & 0.00 \\
TUR & .001 & 0.00 & .000 & 0.00 & .000 & 0.00 \\
ZAF & .002 & 0.00 & $-.007^{* *}$ & 0.07 & $-.013^{* * *}$ & 0.12 \\
\hline CHE & .000 & 0.00 & $-.004^{*}$ & 0.06 & .000 & 0.00 \\
EMU & - & & $-.005^{*}$ & 0.05 & - & \\
GBR & .002 & 0.00 & $.006^{* *}$ & 0.07 & .002 & 0.01 \\
JPN & .006 & 0.01 & -.002 & 0.01 & .003 & 0.01 \\
USA & -.002 & 0.00 & - & & -.002 & 0.01 \\
\hline
\end{tabular}

Notes: The table summarizes the results of sequential bivariate regressions of the first difference of the logarithm of the REER on the contemporaneous values of various independent variables. The estimation method is ordinary least squares. ${ }^{* *}$ denotes statistical significance at $1 \%$, ${ }^{* *}$ denotes significance at $5 \%$, and ${ }^{*}$ denotes significance at $10 \%$.

Short-term interest rate differentials for Brazil and South Africa are based on IFS money market rates instead of three-month bond yields. For Turkey, the overnight borrowing rate is used. 
the REER. The estimated coefficient is statistically significant with the expected sign only for the US.

Except for the UK and Japan, net capital flows ${ }^{25}$ are not coincident with exchange rate movements. However, for these two countries, the sign is counterintuitive. In other words, statistically, there is no link between net capital flows and exchange rate movements in the sample of countries analyzed here. The results for net private capital flows, however, are different. In three of the four emerging market economies, an increase in net private capital flows is associated with a decrease in the exchange rate.

As expected, net portfolio investment flows are negatively associated with exchange rate movements in emerging market economies. This result confirms earlier findings in the literature, as discussed in section 2. The bivariate regressions show that an increase in net portfolio investment flows is coincident with a decrease in the REER in Brazil, India, Turkey and South Africa; the estimated coefficients, which range between -0.24 and -1.69 , are all statistically significant and economically relevant. By contrast, for advanced economies or safe haven currencies, net portfolio investment flows do not appear to be important in explaining the movements of the REER. Among these economies, the estimated coefficient is statistically significant for Japan and the US, although the sign is counterintuitive in both cases.

25 Recall that positive values of net flows are net outflows. Therefore, the expected sign of its coefficient in the regressions is negative. 


\begin{tabular}{|c|c|c|c|c|c|}
\hline & & & 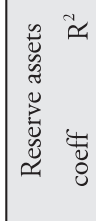 & 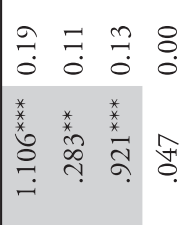 & 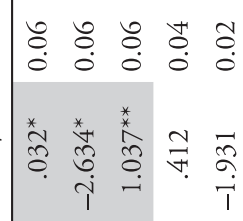 \\
\hline 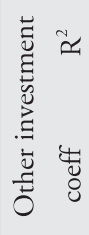 & 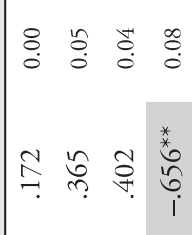 & 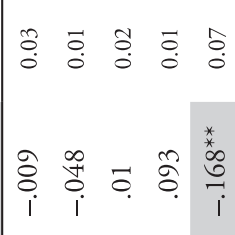 & 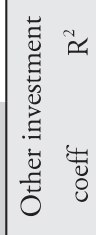 & 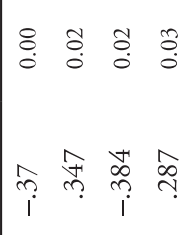 & 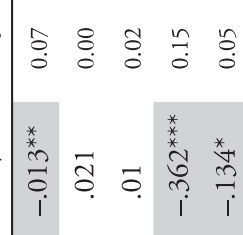 \\
\hline 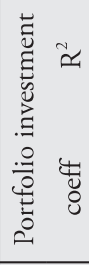 & 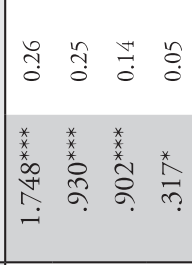 & 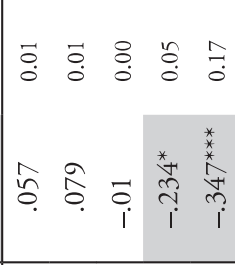 & 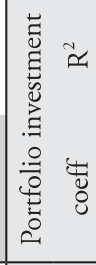 & 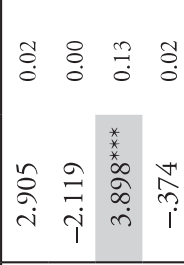 & 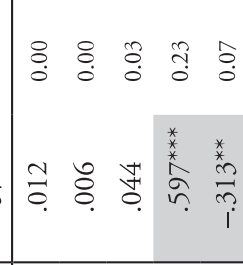 \\
\hline 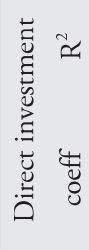 & 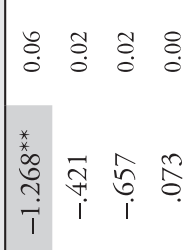 & 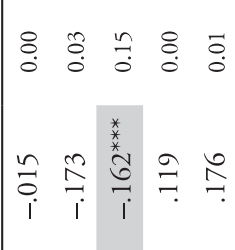 & 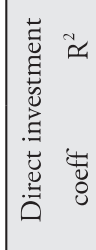 & 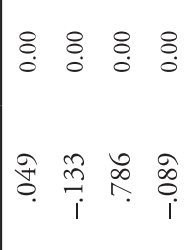 & 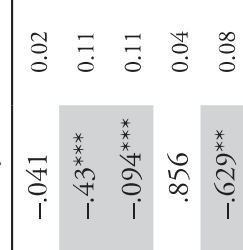 \\
\hline 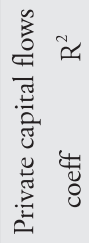 & 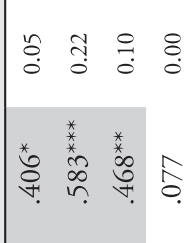 & 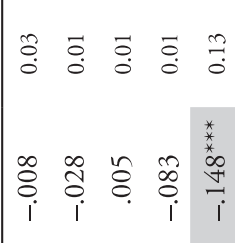 & 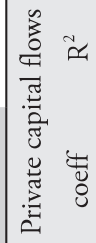 & 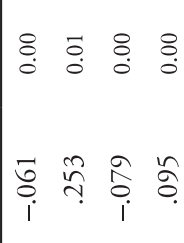 & 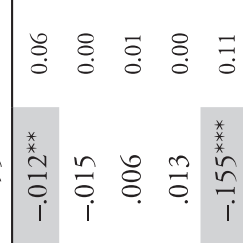 \\
\hline 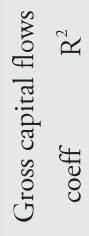 & 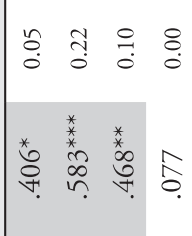 & 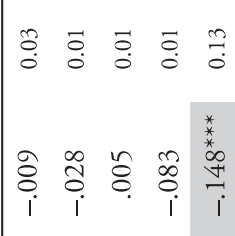 & 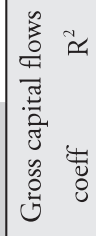 & 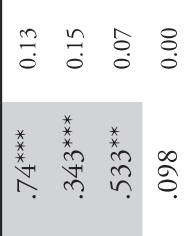 & 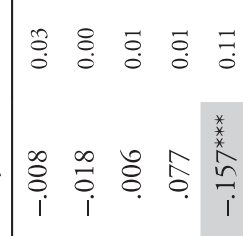 \\
\hline 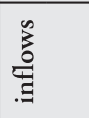 & 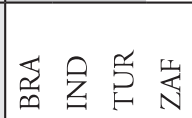 & 岕忌蛋芯志 & 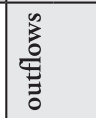 & 吉员苫岕 & 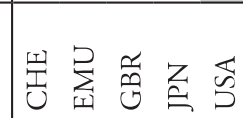 \\
\hline
\end{tabular}

Swiss Journal of Economics and Statistics, 2017, Vol. 153 (4) 


\begin{tabular}{|c|c|c|c|}
\hline 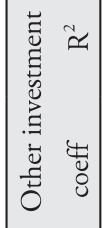 & 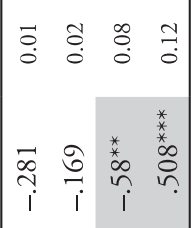 & 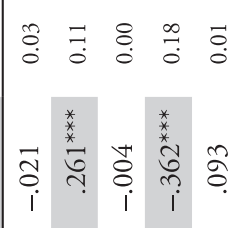 & \\
\hline 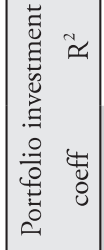 & 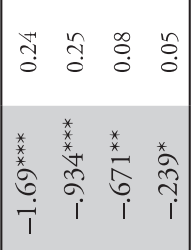 & 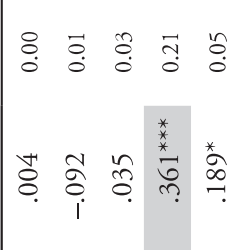 & \\
\hline 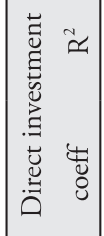 & 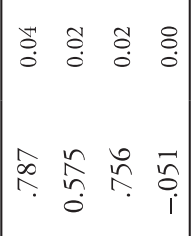 & 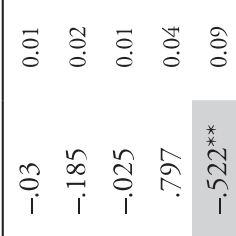 & \\
\hline 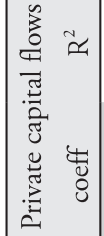 & 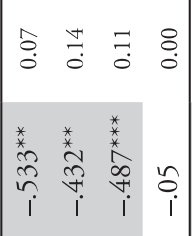 & 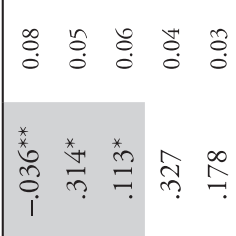 & \\
\hline 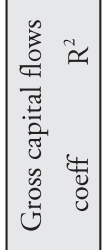 & 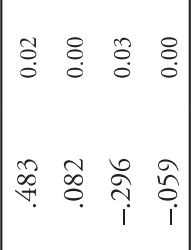 & 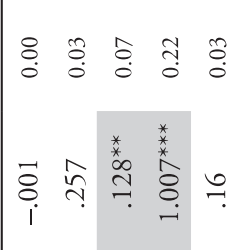 & \\
\hline 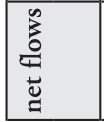 & 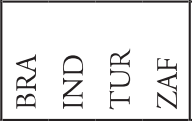 & 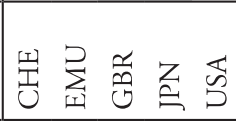 & \\
\hline
\end{tabular}

Swiss Journal of Economics and Statistics, 2017, Vol. 153 (4) 


\section{Conclusion}

This paper analyzes the relationship between the movements of a safe haven currency, the CHF, and capital flows to and from Switzerland. The main finding is that capital flows have little explanatory power in tracking the movements of the REER of the CHF. This result challenges the presumption that capital flows are the main mechanism behind the appreciation of the CHF as a safe haven currency during the recent global turmoil. The results are robust to different model specifications and various types of gross or net capital flows considered in this study. This finding should not be surprising considering earlier findings in the financial economics literature, where asset prices can change drastically without major shifts in portfolios.

The paper also provides empirical evidence that factors other than capital flows were coincident with the appreciation of the CHF during the euro area sovereign debt crisis. In particular, financial market uncertainty variables have been found to persistently co-move with $\mathrm{CHF}$ movements.

One should be cautious in interpreting these results. First, the analysis does not address the endogeneity problem that current and expected exchange rates also affect capital flows. It merely studies the role of capital flows in explaining the REER. Second, the analysis cannot conclusively show a causality relationship between the two variables but merely provides an indication that co-movement of capital flows and exchange rates might possibly be identified. Third, as Switzerland is a financial center with deep markets and as cross-border transactions can take place in currencies other than the CHF, the possibility of a link between capital flows and the exchange rate of the CHF as a safe haven currency may be weakened.

Even when the possible shortcomings of this study are considered, statistical evidence that capital flows drive the movements of the CHF remains lacking. This study's findings suggest that the appreciation of the CHF may have been due to a mechanism other than higher capital (in)flows during the recent global turmoil. This is a topic for further research. 


\section{Appendix A}

Table A1: Capital Flow Variables

Gross capital outflows

Net acquisition of financial assets, i.e., net changes in financial assets held abroad. Positive values indicate an increase in foreign assets.

\section{Gross capital inflows}

Net incurrence of liabilities, i.e., net changes in liabilities toward nonresidents. Positive values indicate an increase in foreign liabilities.

\section{Net capital flows}

Difference between gross capital outflows and gross capital inflows. Also called net lending/net borrowing. Positive values indicate net capital outflows.

\section{Private capital flows versus public capital flows}

Gross capital flows consist of private capital flows and public capital flows. Public capital flows are defined as flows that go to or emanate from the public sector, while private capital flows are defined as the residual. In particular, reserve accumulation by central banks is included in public capital flows. Private capital flows shown in this paper are the author's own calculations based on balance of payments statistics.

\section{Components/categories of capital flows}

\section{Direct investment}

Cross-border investment associated with a resident in one economy having control or a significant degree of influence on the management of an enterprise that resides in another economy. This refers to ownership of at least 10 percent of the voting stock of a cross-border company, or the establishment of a subsidiary or branch.

- Equity capital

Exceptional dividend payments, contributions to cover losses made to direct investment enterprises

- Reinvested earnings

Direct investor's share of the retained earnings or net savings of the direct investment enterprise. Can be negative if losses are incurred by the direct investment enterprise or if dividends payable in a period are larger than net earnings for that period

- Debt instruments

Loans with equity characteristics granted to direct investment enterprises

Portfolio investment

Cross-border transactions and positions involving debt or equity securities, other than those included in direct investment or reserve assets.

- Debt securities

Money market instruments, bonds

- Equity securities

Shares, collective investment schemes 


\section{Other investment}

Residual category that includes positions and transactions other than those included in direct investment, portfolio investment, financial derivatives, and reserve assets

\section{- Bank lending}

Currency, deposits, and loans by banks. Interbank lending operations, lending to customers, mortgage claims, and precious metal claims by deposit including institutions other than central banks

- Other sectors lending

Currency, deposits, and loans by other financial corporations, nonfinancial corporations, households, and money market funds

\section{Reserve assets}

External assets that are readily available to and controlled by monetary authorities for financing needs with respect to balance of payments, for intervention in exchange markets aimed at influencing the currency exchange rate, and for other related purposes. Such assets include changes in gold holdings, foreign exchange holdings, a reserve position in the IMF, and international payment instruments (SDRs)

\section{- Foreign currency investment}

Changes in foreign exchange holdings

\section{Derivatives}

Net payments received for derivatives. This category is identified separately from the other categories because it relates to the transfer of risk rather than the supply of funds or other resources.

Sources: International Monetary Fund, Balance of Payments Manual, Sixth Edition, http://www.imf.org/external/pubs/ft/bop/2007/bopman6.htm http://data.imf.org/

Swiss National Bank, Switzerland's Balance of Payments http://www.snb.ch/en/iabout/stat/bpm6/id/stat_bpm6_uebersicht http://data.snb.ch/en 
Table A2: Other Variables Used in the Empirical Analysis

\section{REER}

The real effective exchange rate (REER) based on a broad basket and deflated by relative consumer prices. Quarterly average values are used in the empirical analysis.

Source: BIS

\section{NEER}

The nominal effective exchange rate (NEER) based on a broad basket. Quarterly average values are used in the empirical analysis.

Source: BIS

VIX

The VIX is the market volatility index of the Chicago Board Options Exchange (CBOE). It is a measure of the market expectations of near-term volatility based on S\&P 500 Index option prices. High VIX values indicate that investors see significant risk that the US financial markets will move sharply, either downward or upward. The empirical analysis uses average VIX values during each quarter.

Source: Datastream

\section{VSTOXX}

The VSTOXX is the European volatility index. It is a measure of the market expectations of near-term volatility based on STOXX 50 option prices. High VSTOXX values indicate that investors see significant risk that the European financial markets will move sharply, either downward or upward. The empirical analysis uses average VSTOXX values during each quarter.

Source: Datastream

Long-term interest rate differential between the US and Switzerland

Yield on 10-year US federal government security (not inflation adjusted) minus yield on Swiss

Confederation 10-year bond yield (not inflation adjusted).

Source: Thomson Reuters Datastream

Long-term interest rate differential between the euro area governments and Switzerland Euro area 10-year government bond yield minus Swiss Confederation 10-year bond yield (not inflation adjusted) where euro area yields are weighted averages of national government bond yields and where the weights are the nominal outstanding amounts of government bonds. Source: Thomason Reuters Datastream

Short-term interest rate differential between the US and Switzerland Money market spreads for short-term (3 month) interest rates for the US and for Switzerland Source: Bloomberg

Short-term interest rate differential between the euro area and Switzerland Money market spreads for short-term (3 month) interest rates for the euro area and Switzerland

Source: Bloomberg 
Dummy1

Dummy variable that captures the foreign exchange market interventions conducted by the Swiss National Bank from February 2009 until May 2010. The dummy variable takes the value one during 2009:Q2-2010:Q2 and zero otherwise.

Dummy2

Dummy variable that captures the minimum exchange rate policy of 1 euro $=1.20$ Swiss francs that was implemented by the Swiss National Bank from September 2011 until January 2015. The dummy variable takes the value one during 2011:Q3-2014:Q4 and zero otherwise.

Dummy3

Dummy variable that captures the rapid appreciation of the Swiss franc between June 2010 and September 2011. The dummy variable takes the value one during 2010:Q3-2011:Q2 and zero otherwise.

\section{References}

Altermatt, Lukas and Romain Baeriswyl (2015), "The effect of the monetary base expansion on the balance sheet of domestic banks", SNB Quarterly Bulletin, No.2015.Q1, Swiss National Bank.

Auer, Raphael (2015), "A safe haven: international demand for Swiss francs during the Euro Area debt crisis", SNB Quarterly Bulletin, No 2015.Q2, Swiss National Bank.

Avdjiev, Stefan, Robert N. McCauley, and Hyun Song Shin (2015), "Breaking free of the triple coincidence in international finance", BIS Working Papers, No.524, Bank for International Settlements.

Bakardzhieva, Damyana, Sami Ben Naceur, and Bassem Kamar (2010), "The impact of capital and foreign exchange flows on the competitiveness of developing countries", IMF Working Paper, No. 10/154, International Monetary Fund.

Botman, Dennis, Irineu de Carvalho Filho, and W. Raphael lam (2013), "The curious case of the Yen as a safe-haven currency: a forensic analysis", IMF Working Paper, No. 228, International Monetary Fund.

Broner, Fernando, Tatiana Didier, Aitor Erce, and Sergio L. SchmukLER (2013), "Gross capital flows: dynamics and crises", Journal of Monetary Economics, 60(1), pp. 113-133.

Brooks, Robin, Hali Edison, Manmohan S. Kumar, and Torsten SløK (2004), "Exchange rates and capital flows", European Financial Management, 10(3), pp. 511-533. 
Brunnermeier, Markus K., Stefan Nagel, and Lasse H. Pederson (2008), "Carry trades and currency crashes", in NBER Macroeconomics Annual 2008, Daron Acemoglu, Kenneth Rogoff, and Michael Woodford, eds., vol.23, pp. 313-347.

Bruno, Valentina and Hyun Song Shin (2013), "Capital flows, cross-border banking and global liquidity”, NBER Working Paper, No. 19038, National Bureau of Economic Research.

Combes, Jean-Louis, Tidiane Kinda, and Patrick Plane (2012), "Capital flows, exchange rate flexibility, and the real exchange rate", Journal of Macroeconomics, 34(4), pp. 1034-1043.

De Bock, Reinout and Irineu de Carvalho Filho (2015), "The behavior of currencies during risk-off episodes", Journal of International Money and Finance, 53, pp. 218-234.

De Carvalho Filho, Irineu (2015), "Risk-off episodes and Swiss franc appreciation: the role of capital flows", German Economic Review, 16(4), pp.439-463.

Dornbusch, Rudiger (1976), "Expectations and exchange rate dynamics", Journal of Political Economy, 84(6), pp. 1161-1176.

Fleming, J. Marcus (1962), "Domestic financial policies under fixed and floating exchange rates", IMF Staff Papers, 9, pp.369-379, International Monetary Fund.

Forbes, Kristin J. and Francis E. Warnock (2012), "Capital flow waves: surges, stops, flight, and retrenchment", Journal of International Economics, 88(2), pp. 235-251.

Galati, Gabriele, Alexandra Heath, and Patrick McGuire (2007), "Evidence of carry trade activity”, BIS Quarterly Review, September, Bank for International Settlements.

Grisse, Christian and Thomas Nitschka (2015), "On financial risk and the safe haven characteristics of Swiss franc exchange rates", Journal of Empirical Finance, 32, pp. 153-164.

Habib, Maurizio Michael and Livio Stracca (2012), "Getting beyond carry trade: What makes a safe haven currency", Journal of International Economics, 87(1), pp. 50-64.

Habib, Maurizio Michael and Livio Stracca (2013), "Foreign investors and risk shocks: seeking a safe haven or running for the exit?", ECB Working Paper Series, No 1609, European Central Bank.

Hoffmann, Mathias and Rahel Suter (2010), "The Swiss franc exchange rate and deviations from uncovered interest parity: global vs domestic factors", Swiss Journal of Economics and Statistics, 146(1), pp. 349-371. 
Hossfeld, Oliver and Ronald MacDonald (2015), "Carry funding and safe haven currencies: A threshold regression approach", Journal of International Money and Finance, 59, pp. 185-202.

IMF (2012), "Article IV staff report on Switzerland", International Monetary Fund.

Kraay, Aart, Norman Loayza, Louis Servén, and Jaume Ventura (2005), "Country portfolios", Journal of the European Economic Association, 3(4), pp. 914-945.

Kugler, Peter and Beatrice Weder (2005), "Why are returns on Swiss franc assets so low?", Applied Economics Quarterly, 51(3), pp. 231-246.

Lane, Philip and Gian Maria Milesi-Ferretti (2007), "Capital flows to central and Eastern Europe", Emerging Markets Review, 8(2), pp. 106-123.

Lartey, Emmanuel K. K. (2008), "Capital inflows, resource reallocation and the real exchange rate", International Finance, 11(2), pp.131-152.

Lartey, Emmanuel K. K. (2011), "Financial openness and the Dutch disease", Review of Development Economics, 15(3), pp. 556-568.

Mancini Griffoli, Tommaso, Christoph Meyer, Jean-March Natal, and Attilio Zanetti (2015), "Determinants of the Swiss franc real exchange rate", Swiss Journal of Economics and Statistics, 151(4), pp. 299-331.

Mundell, Robert (1963), "Capital mobility and stabilization policy under fixed and flexible exchange rates", Canadian Journal of Economics and Political Science, 29(4), pp. 475-485.

OECD (2011), "Economic survey of Switzerland", Organization for Economic Co-operation and Development.

Powell, Andrew and Pilar Tavella (2012), "Capital inflow surges in emerging economies: how worried should LAC be?”, RES Working Papers, No.4782, Inter-American Development Bank Research Department.

Ranaldo, Angelo and Paul Söderlind (2010), "Safe haven currencies", Review of Finance, 14(3), pp.385-407.

Rey, Helene (2015), "Dilemma not trilemma: the global financial cycle and monetary policy independence", NBER Working Paper Series, No. 21162, National Bureau of Economic Research.

Saborowski, Christian (2009), "Capital inflows and the real exchange rate: can financial development cure the Dutch disease?", IMF Working Paper, No. 09/20, International Monetary Fund.

Yeşin, Pinar (2015), "Capital flow waves to and from Switzerland before and after the financial crisis", Swiss Journal of Economics and Statistics, 151(1), pp. 27-75. 